\title{
SEAWARD DRIFT OF THE PONTIC SHAD LARVAE (ALOSA PONTICA) AND THE INFLUENCE OF DANUBE RIVER HYDROLOGY ON THEIR TRAVEL PATH THROUGH THE DANUBE DELTA SYSTEM.
}

\author{
I. NAVODARU \\ Danube Delta National Institute, Babadag str., 165, 8800 TULCEA, Romania.
}

Reçu le 11 septembre 2000

Accepté le 23 février 2001

Received 11 September, 2000

Accepted 23 February, 2001

\begin{abstract}
The Pontic shad lives in the northwestern part of the Black Sea. It migrates in the Danube River for spawning. The larvae drift passively towards the sea when they reach the life stage ranging from pre-larvae to post-larvae. During the larval stage the Pontic shad is floating, mainly in the $\mathbf{0 - 5 0} \mathrm{cm}$ upper layer of river. Upstream of the Danube Delta, in the straight sector of the river, alosids are distributed mostly towards the middle of the river, where the water velocity is higher. In the curved section of the river, upstream of the location of the Danube River splitting in the delta's branches, the water current is outwardly pushing the shad larvae to the right shore, the Romanian, respectively. Therefore, Tulcea branch (Romanian) takes over $60-80 \%$ from the total of Danubian larvae, even its water flow is smaller (40\%) than Chilia branch (the border of Romania and Ukraine). The distribution of larvae at the splitting point influences the repartition of adult migratory catch, at return for spawning, between Saint George branch (Romania) and Chilia branch. Consequently, the topography and hydrology of the river at the splitting point of the branceh which form the delta decide on the distribution of larvae, and later, when the shads are homing on the same way for spawning the sharing catch between Romania and Ukraine.
\end{abstract}

Key-words : Pontic shad, larvae, drifting, distribution, homing, Danube River.

\section{DISTRIBUTION DE LA DÉRIVE VERS LA MER DES LARVES D'ALOSES DE LA MER NOIRE (ALOSA PONTICA) DANS LE DANUBE AU NIVEAU DE LA SÉPARATION DES BRANCHES DU DELTA.}

\section{RÉSUMÉ}

L'alose de la mer Noire vit dans la partie Nord Ouest de la mer Noire. Elle remonte pondre dans le Danube. Les jeunes dérivent passivement vers la mer entre le stade prélarvaire et post-larvaire. A son stade larvaire, l'alose de la mer Noire flotte en grand nombre à la surface de l'eau dans les 0 à $50 \mathrm{~cm}$ de profondeur. En amont du delta, dans le secteur rectiligne du fleuve, les aloses se tiennent en majorité au milieu du lit, où la vitesse du courant est la plus forte. Dans les parties incurvées du fleuve, en amont de la séparation des branches du delta, le courant pousse apparemment les larves d'aloses vers la rive droite, roumaine. Ainsi, la branche de Tulcea (roumaine) reçoit plus de 60$80 \%$ des larves du Danube, même si son débit est plus faible $(40 \%)$ que celui de la branche de Chilia (frontière entre la Roumanie et l'Ukraine). La distribution des larves au 
point de séparation des bras reflète la répartition des captures d'adultes en migration de reproduction, entre la branche de Saint George (Roumanie) et la branche de Chilia. En conséquence, la topographie et l'hydrologie de la rivière au point de séparation des bras du delta décident de la distribution des larves, et ensuite, lorsque les aloses reviennent en suivant le même chemin pour se reproduire, expliquent la répartition des captures entre la Roumanie et l'Ukraine.

Mots-clés : alose de la mer Noire, larves, dérive, distribution, Danube, homing.

\section{INTRODUCTION}

The Pontic shad (Alosa pontica Eichvald 1838) is a marine species which can be found in the Black Sea and migrates for spawning in the tributary rivers (KOLAROV, 1991). The northwestern population (Alosa pontica pontica) migrates mainly in the Danube River. Few individuals reached Budapest, in the past (river kilometer 1,650) (BANARESCU, 1964). Shad migration begins in the early spring, when Danube water temperature reaches $3-7.5^{\circ} \mathrm{C}$. Peak migration occurs in April - May at $9-17^{\circ} \mathrm{C}$, and the end in June - July at $22-$ $26^{\circ} \mathrm{C}$ (NAVODARU, 1998). For Romania, Ukraine and Bulgaria, the stock of Pontic shad sustains an important intercept sharing fisheries (NAVODARU, 1998). The spawning takes place between river kilometers 180 and 500 . Eggs are pelagic and larvae drift passively to the Black Sea.

Pontic shad larvae drift to the sea as unequal spots (LEASENCO, 1953), in prelarval to post-larval life stage. Usually, during the seaward drifting, shad juveniles feed intensely on zooplankton (VLADIMIROV, 1953 ; APRAHAMIAN, 1989). In years when the water current was low with high water transparency, some larvae remain in the river and emigrate seaward later, as grownup and fortified fry (LEASENCO, 1953). Also in the Wye river, England, where the freshwater production of suitable prey species is greater and ample cover is available, the juveniles remain and actively feed, until a change in certain physical factors induces the onset of the autumn seaward migration (APRAHAMIAN, 1989).

The strategy of juveniles is to drift rapidly in the river, either actively or passively towards the estuary, or towards an area of high productivity, where the food is abundant and adequate protection exists (as Mc LUSKY (1981), cited by APRAHAMIAN, 1989) described the shad behaviour in Severn River (England).

Historically, shad fry which entered into the floodplain and Danube Delta lakes, used to migrate seaward, in the middle summer and autumn. Some of them were destroyed as by-catch during the river and sea shoreline fishing (BUGAI, 1953 ; LEASENCO, 1953 ; CAUTIS et al., 1957 ; CRISTEA and CRISTEA, 1960). At the moment, due to river embankment, most of larvae drift directly to the sea. However, an important amount of fish juveniles is still destroyed at the irrigation pumping stations or water supply for fish ponds activity (NAVODARU, 1996). The same situation was described by TAVERNY (1990) for the fry shads in the Gironde estuary, formed by Garonne and Dordogne rivers.

The Pontic shad eggs remain pelagic till hatching, unlike the eggs (WALBURG and NICHOLS, 1967) of the American shad (Alosa sapidissima) and the shad species which enter the western European rivers (APRAHAMIAN, 1981). Those eggs, although pelagic after fertilization, sink to the river bottom. VLADIMIROV (1953) recorded in the Danube River the sampling of several shad eggs, closely to the water surface.

Maximum abundance of larvae occurs in the stratum of $0-0.5 \mathrm{~m}$ below surface, and decreases with depth, till lack of detection below of 2-2.5 m (CRISTEA and CRISTEA, 
1960). The distribution of the abundance towards the water surface is in inverse ratio with water transparency (VLADIMIROV, 1953).

The present work highlights the distribution of Pontic shad drifting larvae in the Danube River, upstream from its delta, as well as between delta branches. It is known that the catch of adult shad stock migrating for spawning is fished in Danube Delta branches by Romania (60\%) in the Southern branches (Saint George and Sulina) and by Ukraine (40\%), in the Northern branch (Chilia).

\section{MATERIAL AND METHODS}

Larvae, in the development stage of yolk absorption and complete juvenile metamorphose, were sampled from different cross sections of the Danube River, near the apex of the delta, in the period 1994-1997 (Figure 1).

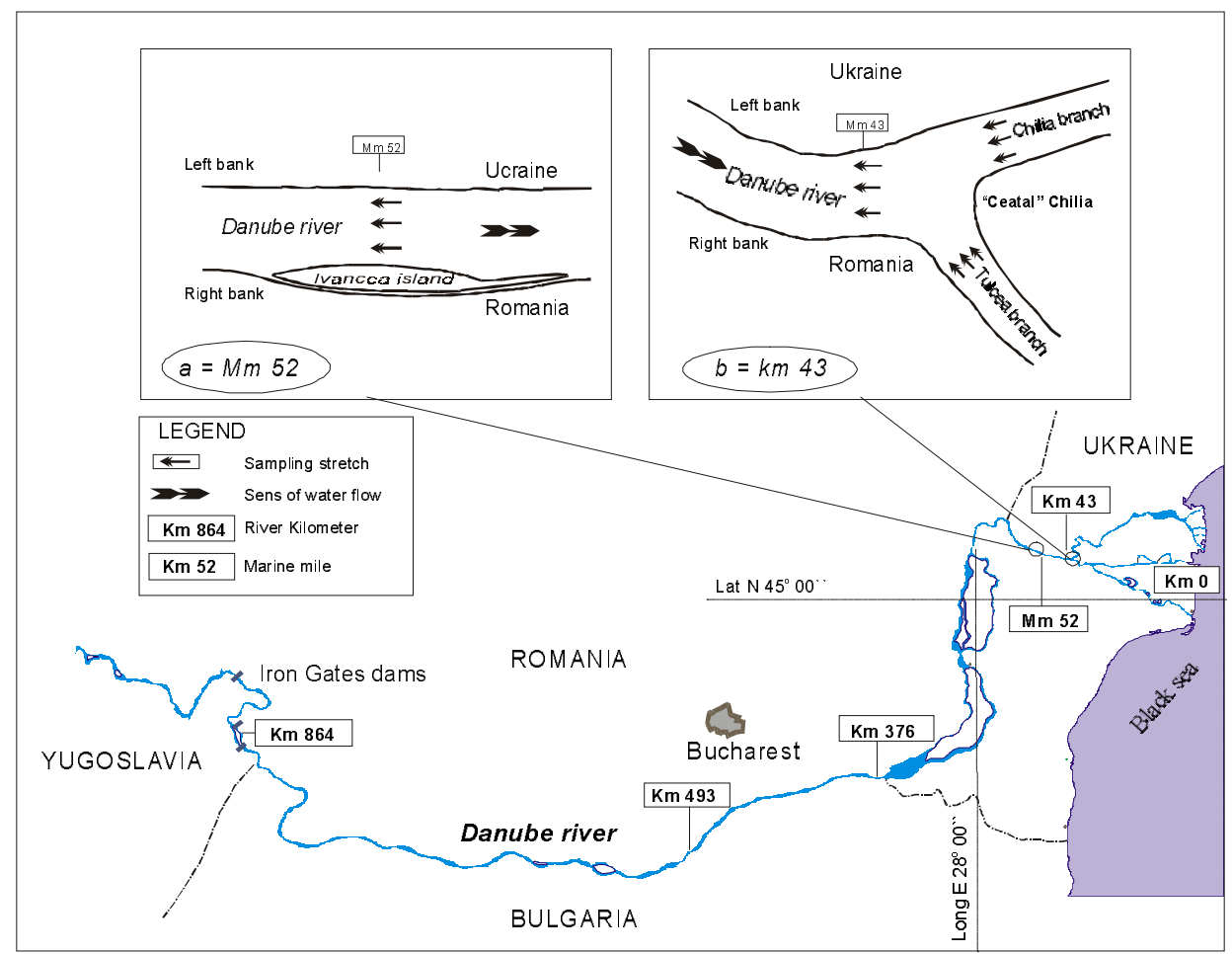

\section{Figure 1}

Location of the Pontic shad larvae sampling sites : Danube River - Mm 52 and «Ceatal » Chilia - Mm 43.

\section{Figure 1}

Localisation des stations d'échantillonnage des larves d'alose de la mer Noire: Danube au point Mm 52 et «Ceatal » Chilia au point Mm 43.

Samples were taken from larvae which were drifting in the Danube River at Marine (nautical) mile $(\mathrm{Mm}) 52$ cross section, upstream from the mouth. Three units were sampled towards the right river bank (20-50 m distance from the river bank), three in the middle of the river, and three on the left bank (20-50 m distance from the left bank) (Figure 1a). The river cross section is approximately $600 \mathrm{~m}$ width, $20 \mathrm{~m}$ depth, average water flow $6500 \mathrm{~m}^{3} / \mathrm{s}$, with a maximum of $13,000-15,000 \mathrm{~m}^{3} / \mathrm{s}$. The depth and river bed shape at the Mm 52 was estimated with a simple echosounder (Humminbird). 
The larval distribution study was studied at Danube River splitting into delta branches, Mm 43 (referred by Romanians as "Ceatal Chilia ») - one section was located upstream in the Danube River, a second section downstream in Chilia branch, and a third in Tulcea branch). On each river section three stations have been established (Figure 1b). Surveys were conducted yearly, from April to August, with weekly or monthly frequency.

Larvae were sampled using a single conical shaped net (Bongo net), of $0.5 \mathrm{~m}$ in diameter, $1.35 \mathrm{~m}$ length, $0.4 \mathrm{~m}$ for cod end length with $0.5 \mathrm{~mm}$ bar mesh size.

Trawls were performed against the water current, in the 0-0.5 m upper water layer, for 3-5 minutes, using a 150 HP boat.

In order to estimate the water volume filtered, a mechanical flowmeter, type $2030^{*}$, was used. It was fixed on the Bongo net ring, with a rope at $1 / 3$ distance from the one attachment point and 2/3 from the other. The distance of trawling in stagnant water or the recorded water volume in both stagnant or running water can be calculated using the flowmeter, by counting the number of rotations.

Trawling distance is given by formula :

$$
\mathrm{L}=\left[\left(\mathrm{N}_{2}-\mathrm{N}_{1}\right) / 999999\right]^{*} \mathrm{~K}
$$

where $L$ is distance in $m, N_{1}$ is number of rotations, read at the trawling start, $N_{2}$ is the number of rotations, read at the end of trawling, $\mathrm{K}$ is the rotor constant $=26873$.

Filtered water volume is given by formula :

$$
\begin{aligned}
& V F=\left[\left(\pi^{*} D^{2}\right) / 4\right]^{*} \mathrm{~L} \\
& \text { or } \\
& V F=0.0053^{*}\left(\mathrm{~N}_{2}-\mathrm{N}_{1}\right)
\end{aligned}
$$

where $D$ is the diameter of the Bongo net opening $=0.5 \mathrm{~m}$.

The most important parameter used to assess the abundance of drifting larvae individuals $/ \mathrm{m}^{3}$ - is the filtered water volume, which can be calculated and is not influenced by the two opposite oriented vectors : the water movement (oriented downstream) and the movement of the trawling boat (oriented upstream).

The samples were preserved in $10 \%$ buffered Formalin, containing formaldehyde, mono-sodium phosphate and distilled water.

Shad larvae were counted, in order to assess their abundance. Up to 300 individuals per sample were measured, at $0.1 \mathrm{~mm}$ precision for size distribution and life stage analysis. Subsampling method through repeated dilution was used for the samples with high abundance. The result obtained has been multiplied with the number of dilutions. The relative abundance is expressed in decimal numbers.

Life stages were identified using the total body length of larvae, according the scale of VLADIMIROV (1953), briefly presented in Table I.

Shad larvae can be easily distinguished from other fish larvae, being long, filiform and translucent.

\footnotetext{
* 1983 - Digital Flowmeter Manual. General Oceanics, Inc. 1295 NW 163rd Street. Miami, Florida 33169 USA.
} 


\section{Table I}

Early life stage development of Pontic shad, made after the scale of Vladimirov (1953).

\section{Tableau I}

Premiers stades de développement de l'alose de la mer Noire, suivant la classification de Vladimirov (1953).

\begin{tabular}{llccc}
\hline Stage & Description & Duration & \multicolumn{2}{c}{ Length (mm) } \\
& (end of stage) & (days) & mean & limits \\
\hline Stage I (pre-larvae) & absorption of yolk & 7 & 6.9 & $5.6-8.0$ \\
Stage II (larvae) & appearance of dorsal fins & 7.1 & $5.7-8.6$ \\
Stage III (larvae) & appearance of anal fins & 10 & 8.2 & $6.8-10.4$ \\
Stage IV (post-larvae) & appearance of ventral fins & & 10.9 & $9.4-14$. \\
Stage V (post-larvae) & young fish & & 15.6 & $11.5-23$ \\
\hline
\end{tabular}

\section{RESULTS AND DISCUSSION}

\section{Life stages of the drifting shad larvae}

In 1994, most of the larvae passing the cross section of Danube River at Mm 52 were classified as stages I (pre-larvae), II and III (larvae). There were fewer juveniles in stage IV and V (post-larvae), due perhaps to survival rate or avoidance of ichthyoplankton net by larger fry (Figure 2). The I-III life stages are dominant in time, being a reflection of the long river spawning sector and duration of the spawning.

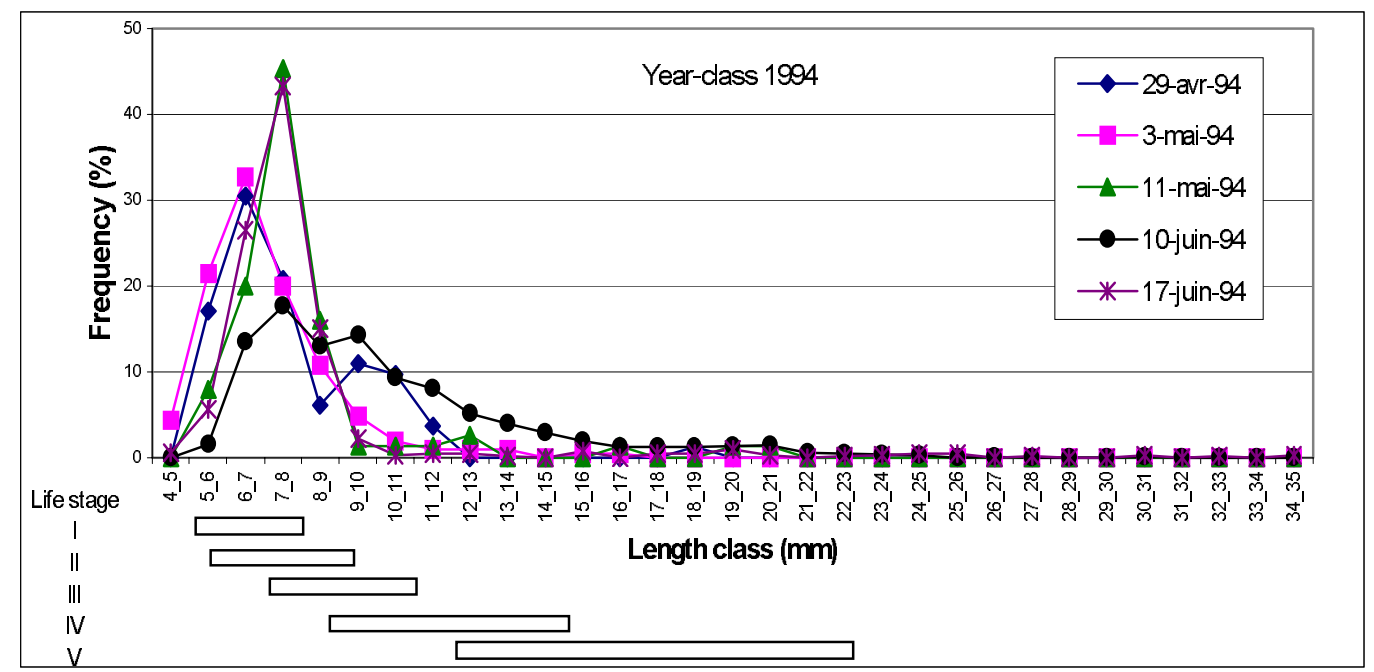

Figure 2

Temporal distribution according to length class and life stage of larvae passively drifting in 1994 at Mm 52 cross section of Danube River.

\section{Figure 2}

Distribution temporelle des larves dérivant passivement en 1994 au niveau de la section transversale du point Mm 52 du Danube, suivant leur classe de taille et leur stade de développement. 
In terms of spatial distribution, shad in length class 6-8 $\mathrm{mm}$ (from the 1995 yearclass), respectively life stages I-III, dominated all the cross sections of the river and the branches (Figure 3).

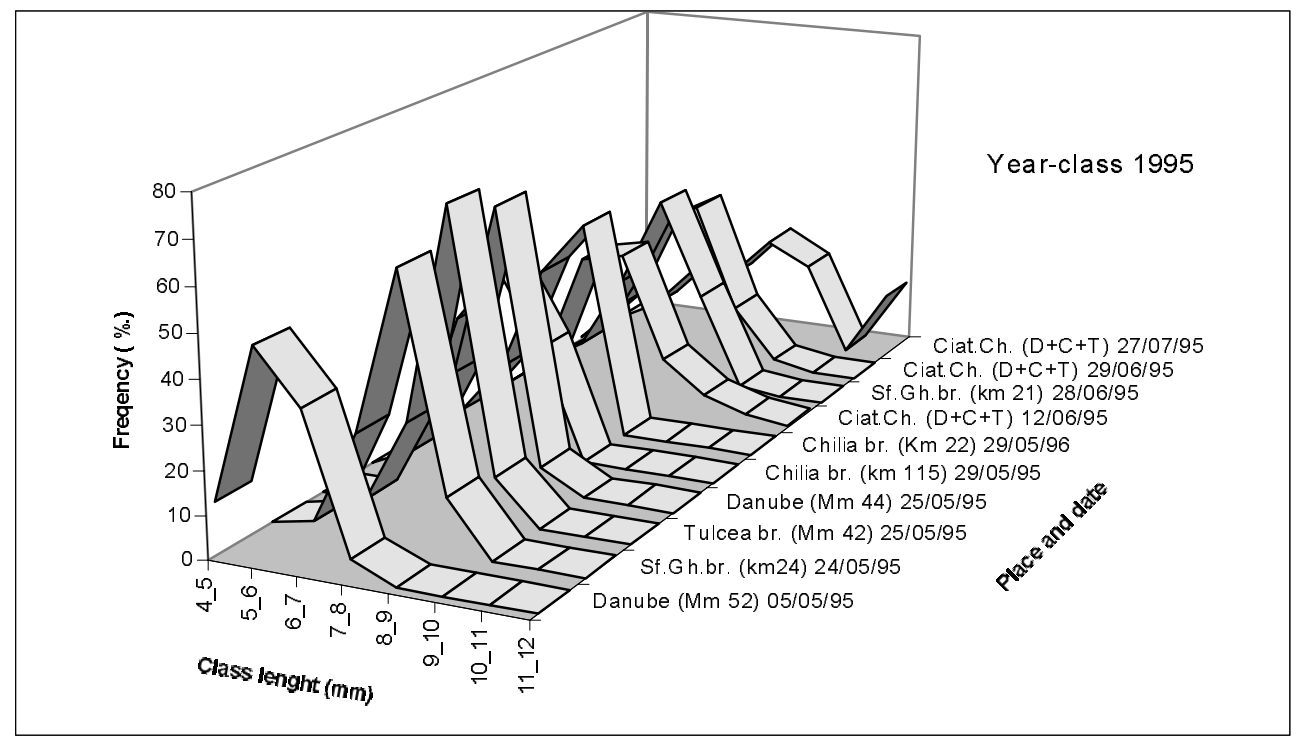

Figure 3

Temporal and spatial distribution of shad larvae from the 1995 year-class $(D+C+T=$ cumulative sampling from "Ceatal » Chilia : $D=$ Danube river, $\mathrm{C}=$ Chilia branch, $\mathbf{T}=$ Tulcea branch ; St.Gh. = Saint George branch ; br. = branch).

\section{Figure 3}

Distribution temporelle et spatiale des larves d'alose de la génération 1995 ( $D+C+T$ = échantillon cumulé de «Ceatal » Chilia : $D=$ Danube, $C=$ Branche de Chilia, $\mathbf{T}=$ Branche de Tulcea, St.Gh. = Branche de Saint George, br. = branche).

Analyzing the three year-classes 1994, 1995 and 1996, we concluded that there is one pattern of drifting life stage ranging from I (pre-larvae) to $\mathrm{V}$ (post-larvae) with maximum I to III (larvae), respectively class length range from $4-5 \mathrm{~mm}$ to $34-35 \mathrm{~mm}$, with peak on 7-8 $\mathrm{mm}$ (Table II).

In Danube River before its delta and delta branches the majority of shad larvae drifts in time and space in life stage I-III, which assumes most larvae drift passively to the Black Sea, where they subsequently feed in the remainder of first year of life. According with the duration of life stages described by VLADIMIROV (1953) it seems that most shad larvae reside in the river only 1 to 3 weeks.

\section{Table II}

Length class frequency distribution of Pontic shad larvae for three year-classes (1994, 1995, 1996).

\section{Tableau II}

Distribution de fréquences des classes de longueur pour les larves d'alose de la mer Noire des trois générations : 1994, 1995 et 1996. 


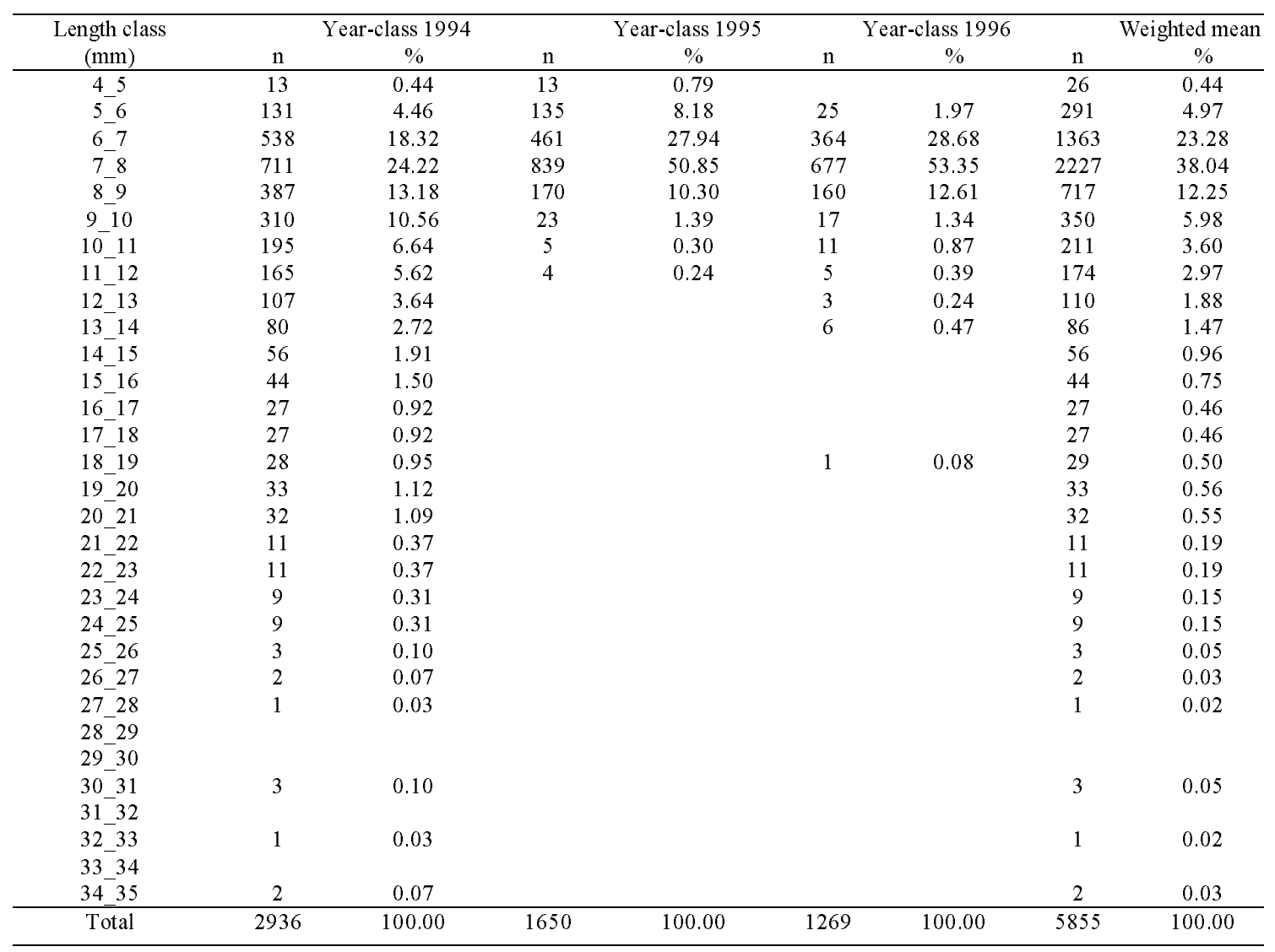

The spatial distribution of drifting larvae on the straight section

The abundance of Pontic shad larvae drifting in 1994 through a straight sector of the Danube River, on the cross section at $\mathrm{Mm} 52$, ranging from 0.16 individuals $/ \mathrm{m}^{3}$ of water to 147.27 individuals $/ \mathrm{m}^{3}$ of water, is related somehow with the dynamics of water temperature (Table III).

\section{Table III}

The drifting abundance of shad larvae through the cross section of Danube River at $\mathrm{Mm}$ 52, in 1994.

\section{Tableau III}

Abondance de la dérive des larves d'alose au travers de la section transversale du Danube au point Mm 52, en 1994.

\begin{tabular}{ccccc}
\hline Date & Volume $\left(\mathrm{m}^{3}\right)$ & No of individuals & $\mathrm{Ind} . / \mathrm{m}^{3}$ & $\mathrm{~T}\left({ }^{\circ} \mathrm{C}\right)$ \\
\hline 29-Apri1-94 & 502.3 & 79 & 0.16 & 15.5 \\
3-May-94 & 434.8 & 198 & 0.47 & 14 \\
11-May-94 & 331.1 & 79 & 0.26 & 15.5 \\
10-June-94 & 555.8 & 71089 & 147.27 & 20 \\
17-June-94 & 402.4 & 1058 & 2.66 & 21 \\
\hline
\end{tabular}


The drifting of larvae took place predominantly in the middle of the strong current stream towards the Romanian right bank, during 1994 ; the drifting along the Ukrainian left bank has been considerably smaller (Figure 4). If we correlate the shad drifting to the shape of river cross section, we may conclude that the strongest current from middle deep riverbed carries more shad larvae. However, the water velocity increases in cross section from banks towards the middle of the stream (CONSTANTINESCU et al., 1956).

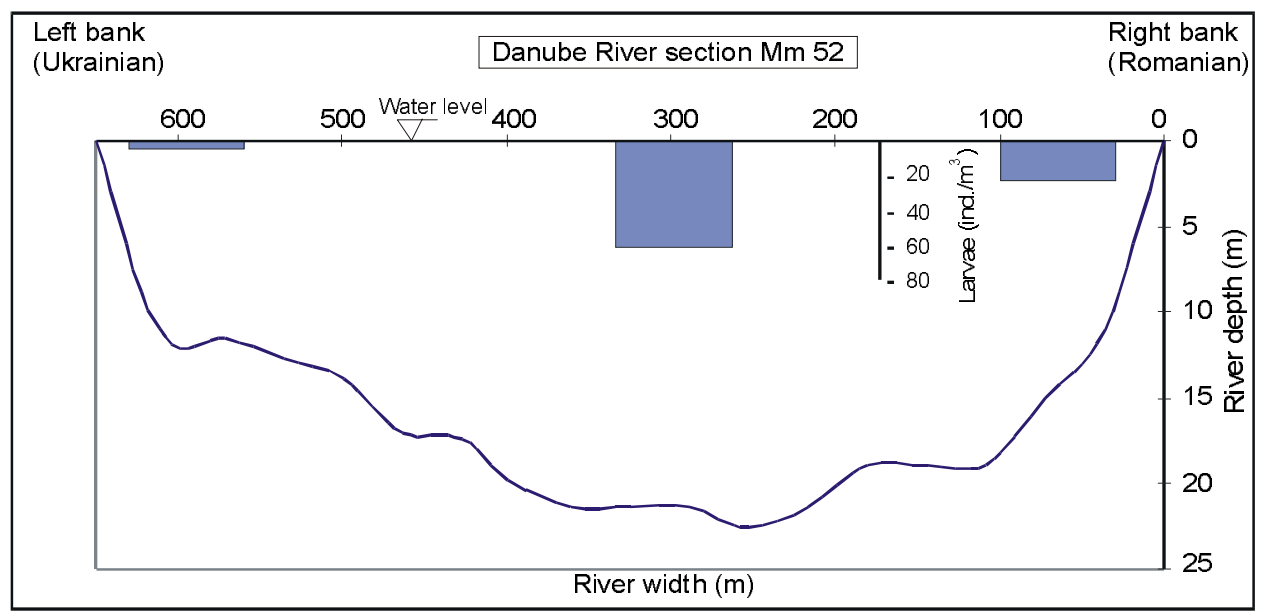

\section{Figure 4}

The distribution of shad larvae drifting in 1994, at Danube River section Mm 52 in the upper 0-0.5 $\mathrm{m}$.

\section{Figure 4}

Distribution de la dérive des larves d'alose en 1994 au niveau de la section du point $\mathrm{Mm} 52$ dans les $\mathbf{0}-0,5 \mathrm{~m}$ sous la surface.

The best physical route for downstream movement for larvae and adult migrants of many species is the channel (KYNARD, 1993). Alosids emigrants feed on zooplankton during emigration. In the Connecticut River the zooplankton abundance is greater in the channel than in shoals even during fall, juvenile shad appear to select a migratory habitat that optimise their needs (DILL, 1987) :

- downstream transportation that minimise physical injury and delay,

- protection from predators,

- foraging on zooplankton.

The upper $0.5 \mathrm{~m}$ of the Danube River (high turbid river), and the zone with maximum water current (middle of the water or the deeper section) provide the optimum habitat for drifting Pontic shad larvae. As a consequence, the maximum abundance of the zooplankton and larvae, which intensively feed, occupy the same habitat.

\section{Abundance distribution of drifting larvae on curve sector and river branches}

On the curved Danube River sector upstream «Ceatal Chilia », at Mm 43, shad larvae drifted predominantly in the middle of the stream and towards the right (Romanian) bank, in May and June, and towards the left (Ukrainian) bank, in July (Table IV). 


\section{Table IV}

Time distribution of drifting larvae (ind. $/ \mathrm{m}^{3}$ ) in curve sector of Danube River upstream of «Ceatal » Chilia (River level = river level at Tulcea in $\mathrm{cm}$ reference point Black Sea) - generation 1996.

\section{Tableau IV}

Chronologie de la dérive des larves (ind. $/ \mathrm{m}^{3}$ ) dans le secteur incurvé du Danube en amont de «Ceatal » Chilia (River level = niveau de la rivière à Tulcea en $\mathrm{cm}$ par rapport au point de référence de la mer Noire) - génération 1996.

\begin{tabular}{|c|c|c|c|c|}
\hline Date & $\begin{array}{l}\text { Left side } \\
\text { of the river }\end{array}$ & Middle & $\begin{array}{l}\text { Right side } \\
\text { of the river }\end{array}$ & $\begin{array}{l}\text { River level } \\
(\mathrm{cm})\end{array}$ \\
\hline 14-Мay-96 & 10.26 & 6.22 & 0.35 & 344 \\
\hline 24-May-96 & 0.84 & 14.21 & 0.13 & 316 \\
\hline 19-June-96 & 0.11 & 0 & 0.02 & 193 \\
\hline 2-July-96 & 0.167 & 0.04 & 0.31 & 110 \\
\hline 16-July-96 & 0.02 & 0 & 0.06 & 154 \\
\hline Mean & 2.28 & 4.09 & 0.17 & 223.4 \\
\hline
\end{tabular}

This is explained by the hydraulic model of the Danube flow, in the «Ceatal » Chilia sector of river, according the water inflow. Thus, when the water flow is high, exceeding $300 \mathrm{~cm}$, near Tulcea town, the channel of the river is right side oriented, and at low water flow, under $200 \mathrm{~cm}$, the channel is left side oriented.

The high water levels of spring flooding period overlapping with the abundant drifting of shad larvae influenced the larvae of the year-classes 1995, 1996 and 1997 to drift more on the right and the middle than on the left side of the river (Figure 5).

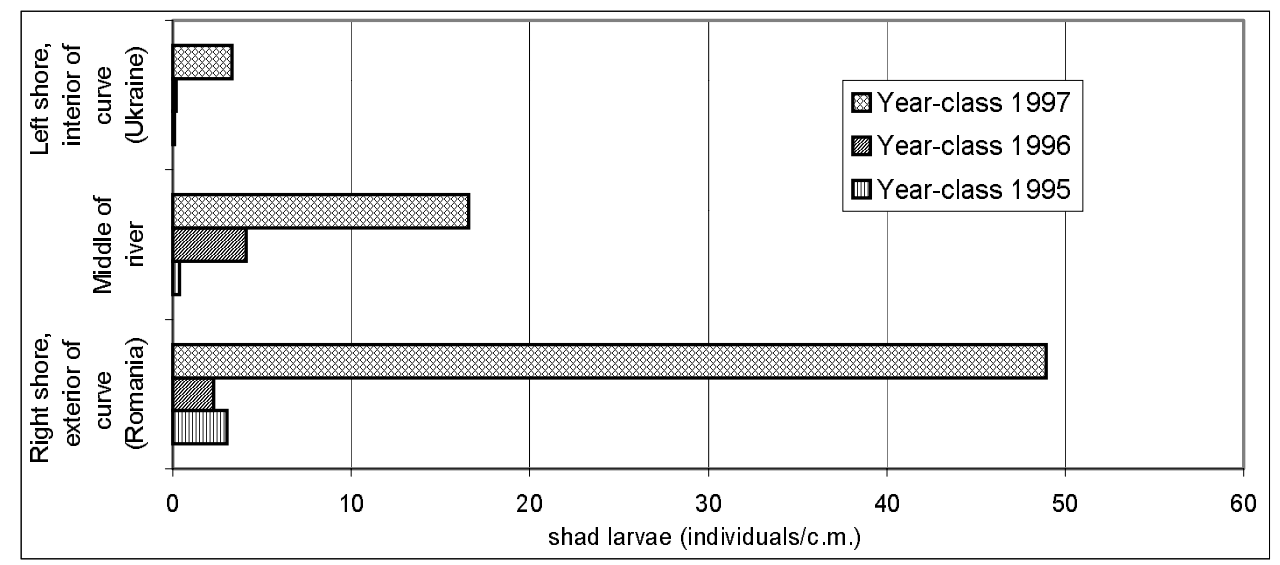

Figure 5

Distribution of drifting shad larvae in curve sector of the Danube River at cross section Mm 43 , during 1995, 1996 and 1997.

\section{Figure 5}

Distribution des larves dérivantes d'alose dans les secteurs incurvés du Danube au niveau de la section transversale du point $\mathrm{Mm} \mathrm{43,} \mathrm{durant} \mathrm{les} \mathrm{années} \mathrm{1995,}$ 1996 et 1997. 
Our findings highlight that, upstream of the splitting point of the Danube River into branches, the shad larvae drift mostly in the middle and towards the Romanian side of the river section.

To verify this distribution of drifting larvae, samples were taken from the two branches, at short intervals, to be able to catch approximately the same larval flux. Accordingly, the quantities of larvae sampled in Tulcea branch were almost two times higher than those drifted on Chilia branch. (Figure 6).

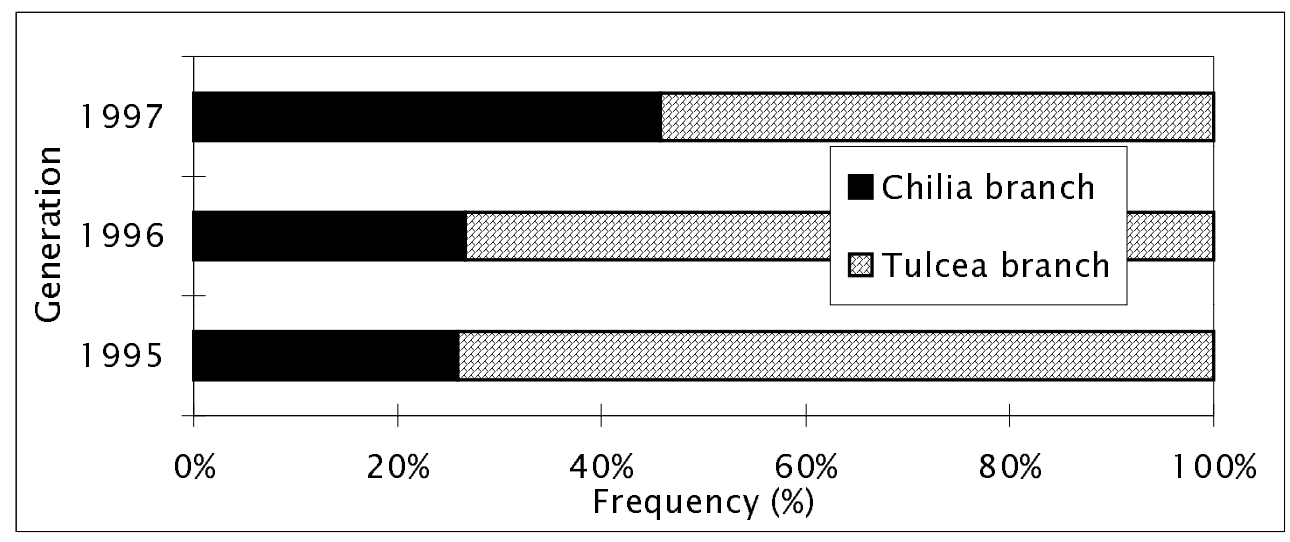

\section{Figure 6}

Quantitative partitioning of drifting shad larvae through Delta branches Tulcea and Chilia, after splitting point in 1995, 1996 and 1997.

\section{Figure 6}

Répartition 1995, 1996 et 1997 des larves dérivantes d'aloses entre les branches du delta de Tulcea et de Chilia, après leur point de séparation.

The analysis of larval distribution at «Ceatal » Chilia (splitting point of the Chilia and Tulcea branches) showed that the most part of larvae drift through Tulcea branch (60$80 \%)$ which discharges less water (40\%), comparing with Chilia branch $(20-40 \%)$, that discharges a larger water amount (60\%).

Long data series of adult migratory shad captures, show a distribution of $40 \%$ for shad caught in Chilia branch, by Ukraine and $60 \%$ in Saint George branch, fished by Romania (Figure 7).

Explanation of the distribution of drifting alosid in inverse proportion to water discharge, is due to the River morphology and hydrology at « Ceatal » Chilia. In the curve sector of Danube River before the splitting point, surface waters together with larvae are pushed towards the exterior of curve on the right shore, as a consequence larvae drift into the Tulcea branch. Hydrodynamics studies show that in curve river sectors the water are pushed towards the exterior, with creation of slight slope of the surface in cross section, increasing from the interior to the exterior of curve, explained by centrifugal forces in the curve (RAUTA et al., 1992). Also the velocity of water increases from the interior of curve, to the exterior of curve (CONSTANTINESCU et al., 1956). 


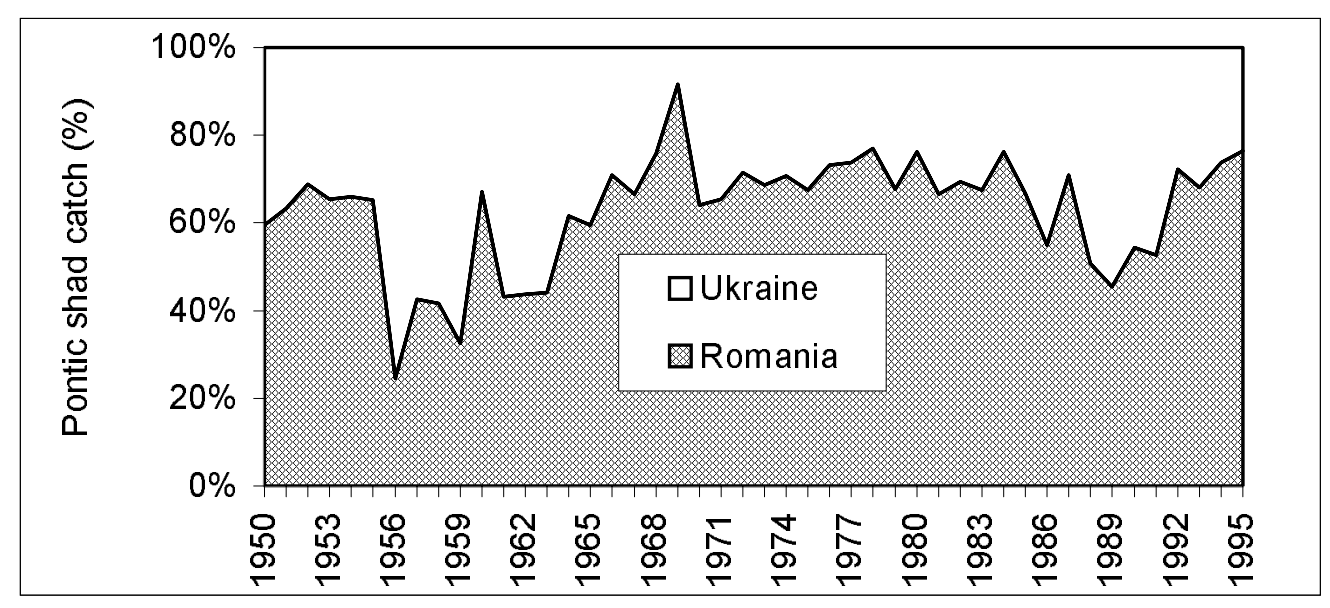

\section{Figure 7}

Catch distribution of Pontic shad between Ukraine (fished in Chilia branch) and Romania (caught in Saint George branch).

\section{Figure 7}

Répartition des captures d'alose de la mer Noire entre l'Ukraine (pêchées dans la branche de Chilia) et la Roumanie (capturées dans la branche de Saint George).

The drifting of a larger amount of larvae on Tulcea branch, followed by Saint George branch, and further pushed towards South by the Black Sea North to South marine current, could be the explanation for the bigger capture in Saint George branch (Romanian) comparing the Chilia branch (Romanian-Ukrainian). Accordingly with homing theory the most migratory adults return for spawning along the same way where larvae « travel » to the sea.

Finally, it appears that morphology and hydrology of the Danube River at « Ceatal » Chilia determine the sharing of migratory shad captures between Romania and Ukraine.

\section{REFERENCES}

APRAHAMIAN M.W., 1981. Aspects of the biology of the twaite shad (Alosa fallax) in the rivers Severn and Wye. Proc. $2^{\text {nd }}$ Brit. Freshw. Fish. Conf., 111-119.

APRAHAMIAN M.W., 1989. The diet of juvenile and adult twait shad Alosa fallax fallax (Lacépède) from the rivers Severn and Wye (Britain). Hydrobiologia, 179, 173-182.

BANARESCU P., 1964. Fauna R.P.R.. Pisces-Osteichthyes. ed Acad. R.P.R., Bucuresti, vol. XIII, 959 p. (in Romanian).

BUGAI K.S., 1953. Zanos licinok dunaiskoi seldi b oz Kagul i skat ee molodi b r. Dunai. In : Dunaiskaia seldi i biologhiceskie osnovî ee promisla., Acad. Nauk., Ukrainskoi SSR., Kiev, 67-85 (in Ukrainian).

CAUTIS I., ILIESCU M., MAXIMOV A., 1957. Probleme fondului de Caspialose din Marea Neagră. Bul. ICP XV (1), p. 47-56.

CONSTANTINESCU M., GOLDSTEIN M., HARAM V., SOLOMON S., 1956. Hidrologie. Ed. Teh. Buc., 449 p. (in Romanian).

CRISTEA A., CRISTEA E., 1960. Observation sur les alevins de Alosa pontica Eichw. pénétrés du Danube dans les lacs du secteur Braila. Bul. ICP, XIX (3), 78-85 (in Romanian with Russian and French abstract). 
DILL L., 1987. Animal decision making and its ecological consequences : the future of aquatic ecology and behavior. Can. J. Zool., 65, 803-811.

KOLAROV P., 1991. Alosa pontica pontica. In : HOESTLAND H. (ed.). The Freshwater Fishes of Europe. Clupeide, Anguilide. AULA-Verlag Wiesbaden, 337-387.

KYNARD B., 1993. Anadromous fish behavior important for fish passage. Can. Tech. Rep. Fish Aquat. Sci., 1905, 95-105.

LEASENCO A.F., 1953. Biologhia molodi dunaiskoi seldi i ee kolocestvennîi ucet. In : Dunaiskaia seld i biologiceskie osnovî ee promîsla. ed. Akad. Nauk Ukrainskoi SSR, Kiev, 85-117 (in Ukrainian).

NAVODARU I., 1996. Spreading of fry Pontic shad (Alosa pontica) on littoral zone in front of Danube delta and destruction by-catch fishing. Scientific Annals of Danube Delta Institute. 5 (2), 287-294 (in Romanian with English abstract).

NAVODARU I., 1998. Pontic Shad: a short review of the species and its fishery. Shad Journal, 3 (4), 3-5.

RAUTA M., CRISTEA V., OPREA L., 1992. Hidrologie. Vol. 1. Univ. Dunarea de Jos din Galati, 352 p.

TAVERNY C., 1990. An attempt to estimate Alosa alosa and Alosa fallax juvenile mortality caused by three types of human activity in the Gironde Estuary, 1985-1986. In: VAN DENSEN W.L.T., STEINMETZ B. and HUGHES R.H. (Eds.), 1990. Management of freshwater fisheries. Proceedings of a symposium organized by EIFAC, Göteborg, Sweden, 31 May-3 June 1988. Pudoc. Wageningen, 215-229.

VLADIMIROV V.I., 1953. Biologhia licinok dunaiscoi i in vijivaemosti. In : Dunaiskaia seldi $i$ biologhiceskie osnovî ee promîsla, Acad. Nauk Ukrainskoi SSR, Kiev, pp. 30-66 (in Ukrainian).

WALBURG C.H., NICHOLS P.R., 1967. Biology and management of the American shad and status of the fisheries. Atlantic coast of the United States, 1960. U.S. Fish Wild. Serv. Spec. Sci. Rep. Fish., 550, 105 p. 